\title{
A Critical Review on Making Low Cost Urban Housing in India
}

\author{
Maulik G. Gangani ${ }^{1}$, Hitendra N. Suthar ${ }^{2}$, Dr. Jayeshkumar Pitroda ${ }^{3}$, Ar. Ruma Singh ${ }^{4}$ \\ ${ }^{1,2}$ Student of third year B.E, Civil Engineering Department, B.V.M Engineering College, Vallabh \\ Vidyanagar-Gujarat-India \\ ${ }^{3}$ Assistant Professor, Civil Engineering Department, B.V.M. Engineering College, Vallabh \\ Vidyanagar-Gujarat-India \\ ${ }^{4}$ Assistant Professor, ShantabenManubhai Patel School of Studies \& Research in Architecture and \\ Interior Design, New Vallabh Vidyanagar-Gujarat-India
}

\begin{abstract}
This research paper aims to study the urban housing problem in India and provide a solution to overcome this. It tries to identify that how can we transfer rural area into urban area and cater the housing needs for below poverty level (BPL) people by providing low cost housing construction techniques which will be economical, fast and better in quality. The article analyses different construction techniques which will be fast and low in cost. It also analyses the different stakeholders and their roles and responsibilities and the user group. Based on the learnings, the research paper tries to propose a accessible and sustainable model to alleviate the housing needs problem.
\end{abstract}

Keywords: Low Cost Urban Housing, Framework, Planning, Construction techniques, Management

\section{INTRODUCTION}

Housing is an arduous problem across the world, especially in developing countries like India. Apart from being one of the three basic necessities of life, adequate housing helps to address an important social determinant of health and prevent diseases, injury and death, provides security and increases household and National income. It has become a top priority for the Government and the society at large to address this issue. This is particularly severe in cities because, by 2025 , more than $50 \%$ of the population is expected to reside in urban settlements in search of stability and income [7]. This would lead to a shortage of 25 Million housing units $-99 \%$ of it being in the Economically Weaker Section and the Low Income Housing space[7]. Through this study we intend to find viable solutions to address the growing problem of low cost urban housing in India.

\section{Present Housing Scenario in India}

India is a populous country where approximately $70 \%$ of the people reside in rural areas [7]. These people are migrating to urban settlements in search of jobs and better living standards.

\section{Scale of the Problem}

The Figure 1, given below shows the State wise and category wise Housing Shortages in India. Here it can be seen that Maharashtra $(1.97 \mathrm{mn})$ has a housing shortage of over 3.7 million homes followed by Tamil Nadu (2.8 mn), Uttar Pradesh (2.4 mn), West Bengal $(2.0 \mathrm{mn}$ ) etc. and India's 99\% urban housing shortage is being primarily driven by the Economically Weaker Section (EWS) and the Low Income Housing ( $\mathrm{LIH})$ categories. 


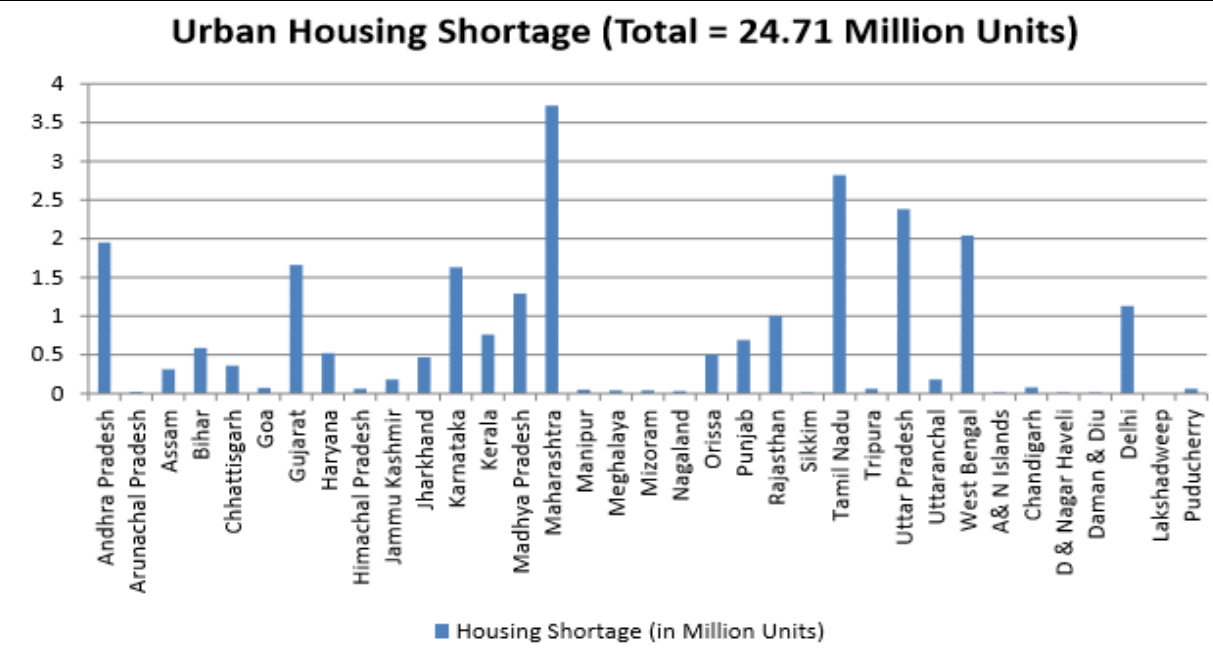

Housing Shortage across Categories (in Million Units)

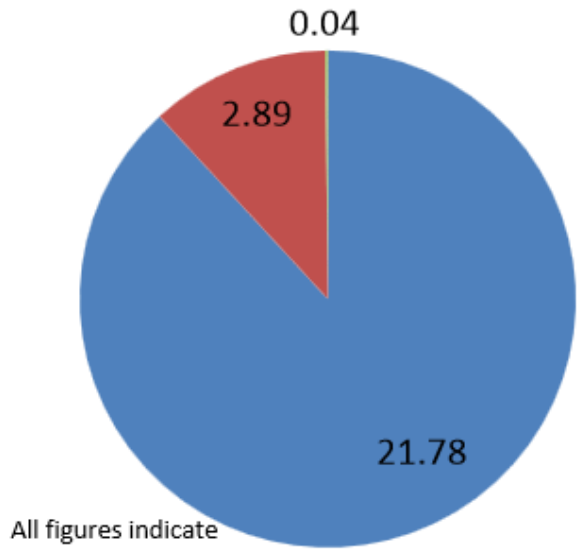

$$
\begin{aligned}
& \text { Economically Weaker } \\
& \text { Sections (EWS) } \\
& \text { < Rs. } 8000 \text { per month } \\
& \text { Low Income Groups (LIG) } \\
& \text { Rs. } 8000 \text { - } 20000 \text { per } \\
& \text { month } \\
& \text { Middle Income Groups } \\
& \text { (MIG) + High Income } \\
& \text { Groups (HIG) } \\
& \text { > Rs. } 20000 \text { per month }
\end{aligned}
$$

Figure1. State wise and category wise Housing Shortages in India

Source: Low Cost Urban Housing in India and Habitat for Humanity

\section{Advantages of Low Cost Housing}

Following are the advantages of the low cost housing:

\subsection{Economic Benefits To The Community}

Affordable housing provides direct economic advantages to the immediate community. Since the houses are affordable, people will have extra money to spend. This is going to lead to an increase in the demand of various services and goods further leading to increased employment opportunities.

\subsection{Provides a diverse workforce}

The best thing about affordable housing is the fact that it accommodates individuals with different skills that are beneficial to the community. For instance, construction workers, bus drivers, cleaners, shop assistants, teachers and nurses are well catered under affordable housing and thus they can provide their important services to the community.

\subsection{Promotes social and economic integration}

Affordable housing ensures low cost housing due to which such families can afford to meet their respective health and education costs. This is also beneficial as it provides an adequate security of tenure for improving an individual's capacity to get and also maintain employment. In addition to that, affordable housing enables people not to migrate from their root place.

\subsection{Stronger labour force}

Through affordable housing, the employees will live near their respective employment centers and this leads to a stronger labour force. The work is also going to be done quickly since the people living 
in the immediate vicinity and can go to work quickly.On the other hand, affordable housing could possibly lead to an increase in traffic due to the increased number of people living in one neighborhood.

\section{Disadvantages of Low Cost Housing}

Issues/ disadvantages for people living in the low cost housing are as following:

1. The low income neighbors are more likely to snipbelongings from you/other neighbours.

2. The residents have limited money so there will be less likely to improve or maintain their homes or the surrounding environments

3. Houses have a simple layout that may or may not have living area separate from a sleeping area and large family inhabit will probably cram 2 people per bedroom and 3 in the living room and make the space over crowded.

4. As there are few official jobs available, people create their own employment: selling items; making any repairing things on a small scale; becoming cleaners, gardeners, taking laundry etc. Hence they will constantly invite their shady friends over which might further leads to the theft and property damage.

5. There will be no choice or control of public type to reside near or adjoin as your neighbours.

\section{Case Studies}

\section{RICS Research report-2010 (Making affordable housing work in India)}

\section{Singapore:}

Singapore had a population of $\sim 4,839,400$ in 2008. Most residential dwellings are "ownership units", developed, financed and (typically) sold to qualifying purchasers by the Housing and Development Board (HDB).

The HDB was established as a government corporation in 1960 and initially focused on providing rental accommodation for low income households. By 1968 the policy shifted to providing a "Home Ownership for the People Scheme" to enable people to buy instead of rent their flats.

Singapore's emphasis on homeownership has become a central social and economic policy of the country with ownership featured as a 'stake' in the prosperity of the Nation and a way to build social cohesion and stability.

The government's mandatory pension plan, the Central Provident Fund, is structured to encourage workers to accumulate a down payment for their HDB home while living with family. At the end of March 2008, 95\% of public flats were owner-occupied, with the rest being rental flats. The government encourages ownership of public flats by providing concessionary home loans and housing grants and by allowing Central Provident Fund savings to be used to finance home purchases, subject to some conditions.

In 1980 the HDB explicitly adopted a policy of multi-cultural mix in buildings and neighborhoods as a means of prompting social stability and ethnic harmony. Singapore annually reports the National household balance sheet with housing values, net of HDB mortgages, highlighted. The HDB housing types are standardized and the size and design is denoted by the number of bedrooms, e.g. an "HDB 1-room" is a one bedroom plus a living room and kitchen.

Organizational Framework and Planning: Singapore's residential development is highly centralized with the Housing and Development Board being the primary builder and manager of residential real estate. HDB develops approximately $80 \%$ of Singapore's housing stock. The organization, a department of the Government, also has the mandate to develop new towns, manage land reclamation, waterfront development, and infrastructure projects. HDB also owns a 75 percent equity interest in a management company that provides commercial property management services and specializes in public housing management for Town Councils.

Construction: HDB retains control over design and planning functions of its comprehensive development projects. A significant proportion of the housing stock is older than 20 years and HDB is undertaking various renewals and upgrading programs. Construction is tendered through a detailed bidding process. 
Management: HDB has an extensive system for allocating units and adjudicating tenant issues and conflicts. HDB has a policy of mixed ethnicity and mixed-income neighborhoods.

The government of Singapore provides rental supplements to qualifying renters within the HDB portfolio. These subsidies and the housing operations are managed by HDB. In 2009 the government of Singapore provided a housing subsidy through HDB of S\$2.04 billion (US\$ 1.44 billion) or approximately $5.45 \%$ of total government expenditures.

The government through the HDB effectively uses housing as a tool to achieve social and political objectives. For instance, before 1991, singles were not allowed to buy HDB flats on their own, in line with the government's pro-family and pro-marriage stance.

However the rule was gradually relaxed, initially giving singles access to three-room or smaller resale flats in certain areas, then to such flats in any location, and now single Singaporeans aged at least 35 years old can purchase resale flats of any size in any location.

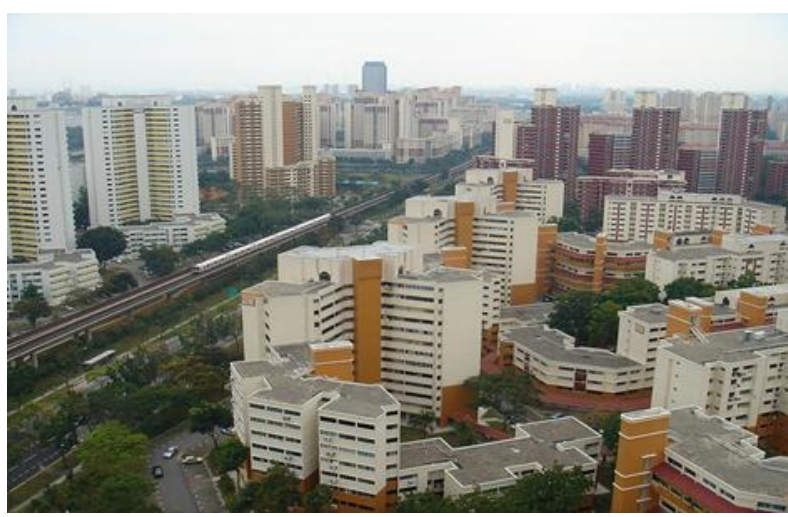

Overview of Bukit Batok, an example of a satellite town developed by the HDB since the 1970s.

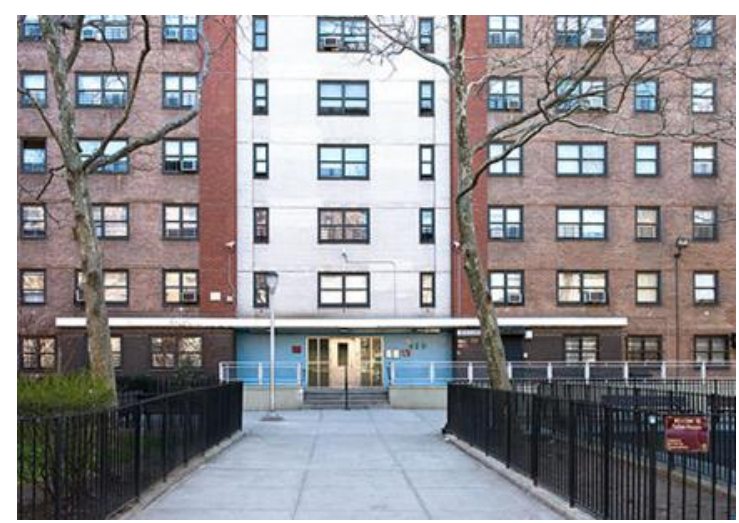

NYCHA's 334 public housing developments include the Fulton Houses in Manhattan, built in 1965.

\section{Conclusions}

Based on Literature Review the conclusions are drawn as following:

1. The magnitude of the Housing problem in India is too large for any single entity to make an impact.

2. The HFH model gives us a sustainable model which is a good starting point. Based on our understanding of the HFH model, we believe that a collective system which incorporates the advantages of each entity with clear cut roles and responsibilities is the most likely solution.

3. It requires collective efforts and efficient co-ordination among these different entities in order to build a scalable and sustainable model that can attempt to address the burgeoning housing problem in India.

\section{ACKNOWLEDGEMENT}

The Authors thankfully acknowledge Dr. C. L. Patel, Chairman, Charutar Vidya Mandal,Er. V.M. Patel, Hon. Jt. Secretary, Charutar Vidya Mandal, Dr. Indrajit N. Patel, Incharge Principle, BVM Engineering Collage, Dr. L. B. Zala, Professor and Head, Civil Engineering Department, BVM Engineering Collage, Dr. Jayeshkumar R. Pitroda, Assistant Professor, Civil Engineering Department, BVM Engineering Collage, Prof. C.B. Mishra, Assistant Professor, BVM Engineering Collage, India for their motivation, support and cooperation to carry out this research.

\section{REFERENCES}

[1] Affordable Housing in England- research paper 06/41, 18 August 2006.

[2] Affordable H8933ousing and the Conflict of Competing Goods: A Policy Dilemma-2009.

[3] Affordable housing: Policy and practice in India, IIMB Management Review (2015), 129-140.

[4] An Evaluation of the Low-Income Housing Sector in Jamaica.

[5] India: Slum-free by 2022? A people-centered evaluation of the PradhanMantriAwashYojana Scheme.

[6] Issue Paper on Affordable Housing City of Calabasas 2030 General Plan Update 
[7] Low cost urban housing in India and habitat for humanity

[8] http://www.jll.co.in/india/engb/Research/Affordable_Housing_in_India_2012.pdf?27e6f5542aa8-4864-8bc3-9127a4b902bc

[9] RICS research report-2010 (Making affordable housing work in India.

[10] http://www.rics.org/in/knowledge/research/research-reports/india-concept-house-/

[11] The Hamilton project-Advancing Opportunity, Prosperity and Growth-Discussion Paper September 2008.

[12] www.ibef.org

\section{AUTHORS' BIOGRAPHY}

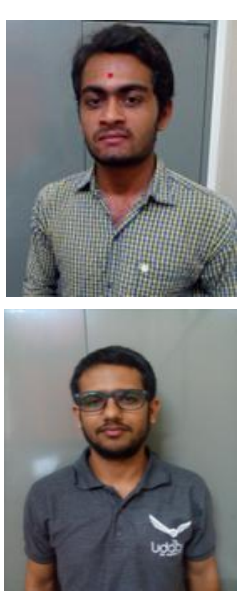

Maulik G. Gangani, is student of third year, B.E. Civil Engineering., BVM Engineering College, Vallabh Vidyanagar-Gujarat-India.

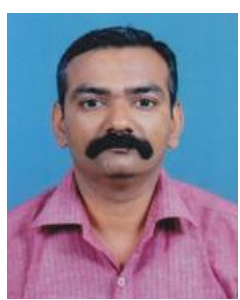

Dr. Jayeshkumar Pitroda, received his Bachelor of Engineering Degree in Civil Engineering from Birla Vishwakarma Mahavidyalaya Engineering College, Sardar Patel University in 2000. In 2009 he received his master's degree in Construction Engineering and Management form Birla Vishwakarma Mahavidyalaya Sardar Patel University. In 2015 he received his Doctor of Philosophy (Ph.D.) Degree in Civil Engineering from Sardar Patel University. He joined Birla Vishwakarma Mahavidyalaya Engineering College as a faculty in 2009, where he is Assistant Professor of Civil Engineering Department with a total experience of 16 years in the field of Research, Designing and Education. He is guiding M.E. / M.Tech (Construction Engineering and Management) thesis work in the field of Civil / Construction Engineering. He has published many papers in National / International Conferences and International Journals. He has published seven Research Books in the field of Civil Engineering, Rural Road Construction, National Highways Construction, Utilization of Industrial Waste, Fly Ash Bricks, Construction Engineering and Management, Eco-friendly Construction.

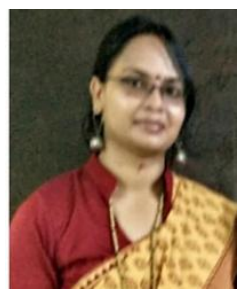

Ar. Ruma Singh, did Bachelor of Architecture from Government College of Architecture, Lucknow and Master's in Regional Planning, School of Planning and Architecture, Delhi. She is having a 4years experience of professional work with various Consultancy and Architectural Firms and 3.5 years in Education field and at present, working as an Assistant Professor in SMAID College, New Vallabh Vidyanagar. 